\title{
ANALISIS PERILAKU KONSUMEN SEGMEN DEWASA MUDA DALAM PENGGUNAAN LAYANAN DARING PERBANKAN: MANFAAT DAN RISIKONYA
}

\author{
Hilarius Bambang Winarko \\ Universitas Siswa Bangsa Internasional
}

\begin{abstract}
Dewasa ini penggunaan layanan daring (online) di industri perbankan semakin memiliki peran penting untuk mendorong kualitas transaksi perbankan modern yang lebih transparan dan efisien. Penerapan layanan daring perbankan tidak terlepas dari peran segmen Dewasa Muda (young adults) karena mereka termasuk dalam generasi yang dekat dengan teknologi informasi dan komunikasi yang semakin bersifat "ubiquitous". Indonesia memiliki profil demografi dimana populasi anak muda yang ada saat ini memiliki potensi besar dalam menyumbang pertumbuhan ekonomi nasional di masa yang akan datang. Studi ini bermaksud untuk mengamati perilaku konsumen khususnya mereka yang tergolong dalam segmen Dewasa Muda, khususnya mereka yang berusia sekitar 1629 tahun, terhadap penggunaan layanan daring perbankan dilihat dari sudut pandang persepsi manfaat dan risikonya. Hasil penelitian studi ini melaporkan adanya perbedaan yang cukup signifikan antara kelompok yang sudah pernah dan kelompok yang belum pernah melakukan layanan daring perbankan. Para pelaku industri perbankan dapat memanfaatkan layanan daring sebagai nilai tambah untuk menjangkau pasar yang lebih luas dengan mengenali kebutuhan (needs) para nasabahnya, khususnya segmen Dewasa Muda.
\end{abstract}

Kata Kunci:

Perilaku Konsumen, Layanan Daring (online), Perbankan, Segmen Dewasa Muda, Pemasaran Jasa, Electronic Banking, E-Commerce, E-Business. 


\section{PENDAHULUAN}

Sistem daring (online) di dalam dunia perbankan bukan hal yang baru seiring dengan meningkatnya penggunaan teknologi berbasis Internet dewasa ini. Bahkan di negara maju seperti misalnya Amerika Serikat, empat dari lima rumah tangganya sekarang sudah menggunakan sistem daring perbankan dengan pertumbuhan yang tetap dari tahun ke tahun seiring dengan pertumbuhan populasi pengguna Internet. Menurut eMarketer, penggunaan sistem daring perbankan tahun 2014 dapat mencapai sekitar 116 juta konsumen. Lebih dari 20\% pengguna Internet, yaitu sekitar 16 juta orang sekarang menggunakan aplikasi perbankan bergerak (mobile) yang dijalankan pada perangkat ponsel pintar (smartphones). Dengan adanya pengembangan sistem daring di masa yang akan datang, struktur industri keuangan secara keseluruhan yang meliputi jasa layanan perbankan, asuransi dan brokerage akan terkonsolidasi menjadi industri suatu jasa keuangan yang lebih terintegrasi (Laudon dan Traver, 2011).

Di Indonesia, sistem daring perbankan dapat dikatakan masih relatif dibandingkan negara-negara maju dan diperkenalkan sejak tahun 1998 oleh Bank Internasional Indonesia, yang kemudian semakin banyak diikuti oleh bank-bank lainnya. Secara masif penggunaan layanan daring perbankan dilakukan oleh Bank Central Asia (Bank BCA) sejak 2001. Selain digunakan untuk melakukan transfer dana secara efektif, layanan daring perbankan juga dilakukan guna mengetahui informasi saldo, mutasi rekening, informasi nilai tukar, pembayaran tagihan seperti misalnya kartu kredit, rekening telepon, rekening listrik, asuransi, dan juga untuk melakukan transaksi pembelian seperti misalnya pembelian pulsa ponsel, tiket pesawat, pembelian saham, dsb. Peraturan Bank Indonesia No. 9/15/PBI/2007
Tahun 2007 tentang Penerapan Manajemen Risiko Dalam Penggunaan Teknologi Informasi Oleh Bank Umum, menunjukkan perhatian yang serius diberikan oleh Pemerintah dalam pengelolaan industri perbankan dengan menggunakan teknologi Internet.

Penggunaan sistem daring perbankan dipercaya mendatangkan manfaat baik dari pihak konsumen maupun dari pihak perbankan, seperti misalnya memberikan kemudahan bagi para nasabahnya, maupun menghemat biaya-biaya yang muncul dalam suatu transaksi perbankan (biaya transportasi, penggunaan kertas dan customer service). Beberapa perusahaan jasa keuangan seperti misalnya: Bank of America, Wells Fargo, Citibank, bahkan mengizinkan nasabahnya untuk dapat melihat gambar (images) dari cheques, invoice serta dokumen korespondensi yang masuk, sehingga nasabah dengan leluasa dapat mengakses ataupun merasa nyaman bertransaksi tanpa harus meninggalkan tempat kerja mereka dan tetap produktif. Di sisi lain, selain manfaat yang diberikan, layanan sistem daring perbankan belum sepenuhnya dipercaya oleh masyarakat dikarenakan mengandung beberapa risiko baik itu risiko finansial, risiko sosial dan faktor keamanannya, terutama masyarakat Indonesia yang relatif baru mengadopsi sistem daring perbankan.

Dengan melihat pesatnya perkembangan sistem daring perbankan ke depan dan dengan melakukan pendekatan analisis dari sisi manfaat dan risikonya, penulis mencoba melakukan suatu penelitian kecil untuk mengenali perilaku konsumen perbankan di Indonesia lebih mendalam terhadap sejumlah kelompok Dewasa Muda yang berusia 16-29 tahun. Mereka dapat dikategorikan sebagai segmen pasar Dewasa Muda bagi para pelaku industri perbankan, yaitu karena mereka yang duduk di bangku 
SMU, perkuliahan, ataupun telah lulus kuliah dan menapaki dunia kerja. Kelompok ini diyakini lebih mandiri daripada generasi sebelumnya sehingga memiliki kebutuhan dalam menggunakan jasa layanan keuangan perbankan, baik dengan sistem perbankan secara tradisional maupun daring.

Adapun studi dilakukan dengan tujuan menggali perbedaan persepsi kelompok Dewasa Muda tersebut terhadap penggunaan layanan daring perbankan, baik kelompok yang sudah pernah melakukan layanan daring perbankan, maupun yang belum pernah. Hasil studi ini diharapkan dapat memberikan kontribusi bagi para pelaku industri perbankan, terutama dalam rangka menyusun strategi layanan daring perbankan dengan memperhatikan faktor positif yang dapat mendorong maupun faktor resistensi yang dapat memperlambat penggunaannya. Ada beberapa limitasi dalam studi ini terkait dengan kompleksitas metodologi penelitian. Namun demikian penulis berharap beberapa temuan mendasar dalam studi ini dapat memperluas penelitianpenelitian berikutnya, yang dapat bermanfaat baik bagi kalangan akademis maupun praktis bisnis, secara khusus bagi para pelaku industri perbankan dan teknologi informasi dan komunikasi di masa yang akan datang.

\section{TINJAUAN PUSTAKA}

Penelitian ini mengambil fokus konsumen segmen kelompok Dewasa Muda dengan pertimbangan bahwa segmen pasar ini diyakini sebagai segmen yang mudah beradaptasi dengan perkembangan teknologi informasi dan komunikasi, sehingga ke depan generasi ini mampu memberikan kontribusi yang cukup berarti terhadap pertumbuhan perekonomian negara. Segmen Dewasa Muda (young adults) yang termasuk dalam Generasi "Millenials" atau Generasi "Echoboomers” atau Generasi Y, merupakan kategorisasi sekelompok individual yang masuk dalam kategorisasi usia 9-32 tahun karena memiliki karakteristik umum yang sejenis dan dipercaya merupakan generasi pertama yang mengadopsi teknologi digital yang semakin ubiquitous (terdapat atau terlihat dimana-mana) sebagai sarana untuk berkomunikasi, mengumpulkan informasi dan berbagi secara bersama (Armstrong dan Kotler, 2010).

Penelitian yang dilakukan di Inggris terhadap 164 responden menemukan bahwa kelompok usia 16-29 tahun secara signifikan memiliki sikap (attitudes) yang lebih positif dan minat (behavioral intentions) yang lebih terhadap penggunaan layanan daring perbankan dibandingkan kelompok usia yang lainnya (Chau dan Ngai, 2010). Dengan mengadopsi penelitian tersebut, maka studi ini melakukan fokus penelitian terhadap segmen kelompok Dewasa Muda yang berusia 16-29 tahun. Penelitian tersebut konsisten dengan studi yang dilakukan oleh McKinsey Global Institute (2012) yang mengatakan bahwa Indonesia memiliki profil demografi termuda di dunia di mana $60 \%$ populasinya berusia di bawah 30 tahun dengan peluang pertumbuhan populasi sebesar 2.5 juta orang per tahunnya. Berdasarkan prediksi McKinsey, pada tahun 2030 terjadi lonjakan potensi konsumen sebesar 90 juta orang dengan pendapatan yang cukup untuk membelanjakan kebutuhan dasarnya, barang dan jasa yang dibutuhkannya, di mana mereka adalah berasal dari kelompok Dewasa Muda sekarang ini.

Dengan asumsi pertumbuhan penggunaan Internet lebih dari 20\% setiap tahunnya, maka diprediksi pada tahun 2016 pengguna Internet di Indonesia dapat mencapai 100 juta orang, di mana sebagian akan menggunakan kemudahaan yang diberikan dalam layanan daring perbankan. Dalam bukunya Electronic Commerce, 
Turban et. al (2012) mendefinisikan kegiatan perbankan dengan layanan daring sebagai serangkaian kegiatan perbankan yang dilakukan dari rumah ataupun di jalan dengan menggunakan koneksi Internet; juga dikenal sebagai cyberbanking, virtual banking, online banking, e-banking atau pun home banking. Di dalam Peraturan Bank Indonesia No. 9/15/PBI/2007 Tahun 2007 juga disebutkan bahwa electronic banking didefinisikan sebagai layanan yang memungkinkan nasabah bank untuk memperoleh informasi, melakukan komunikasi, dan melakukan transaksi perbankan melalui media elektronik antara lain: Anjungan Tunai Mandiri, phone banking, electronic fund transfer, internet banking, dan mobile phone. Beragam jenis sistem aplikasi daring perbankan yang dikembangkan lebih lanjut oleh pelaku industri perbankan dapat dikategorikan dalam lima kelompok besar, yaitu: pertama, sebagai aplikasi yang bersifat informatif, di mana bank memberikan informasi secara umum mengenai perusahaannya; kedua, aplikasi administratif, di mana pihak bank dapat memberikan akses layanan administratif kepada calon nasabah secara daring; ketiga, aplikasi transaksional, di mana nasabah dapat menikmati transaksi perbankan secara efektif; keempat, aplikasi portal, di mana pihak bank menyediakan tautan (links) guna menyediakan berbagai informasi keuangan, komunitas, bisnis, dsb.; dan kelima adalah aplikasi dengan beragam layanan bergerak (wireless) dan fungsi pencarian (search).

Layanan daring perbankan selain memiliki banyak manfaat seperti misalnya lebih praktis dan efisien bagi masyarakat, namun masih ada kelompok konsumen yang menolak untuk mengadopsi penggunaan layanan ini dikarenakan faktor risiko, yaitu ketidakpastian (uncertainty) dan masalah keamanannya (Kuisma et al., 2007; Littler dan Melanthiou, 2006). Dengan menggunakan pendekatan integratif dengan teori TAM (Technology Acceptance Model) yang dikembangkan oleh Davis (1989) dan teori TPB (Theory of Planned Behavior) yang dikembangkan oleh Ajzen (1991), sebuah studi perilaku terhadap layanan daring perbankan dengan pendekatan manfaat dan risiko dilakukan di Taiwan terhadap 368 orang yang sebagian besar berlatar pendidikan tinggi (Lee, 2009). Hasil penelitian tersebut menemukan bahwa minat (intention) untuk menggunakan layanan daring perbankan secara positif dipengaruhi terutama oleh persepsi manfaat (perceived benefit), sikap (attitude) dan kegunaannya (perceived usefulness). Namun sebaliknya (adversely) minat dipengaruhi terutama oleh risiko keamanan/kerahasiaan dan risiko keuangan. Mengacu pada kerangka teori tersebut, maka studi ini dikembangkan dengan bertujuan untuk mengevaluasi persepsi manfaat dan risiko terhadap layanan daring perbankan dengan konteks kultur yang berbeda. Yaitu secara khusus studi dilakukan terhadap segmen Dewasa Muda berusia 16-29 tahun di Indonesia, dengan dua macam fokus obyek pengamatan; baik kelompok yang sudah pernah menggunakan layanan daring perbankan maupun kelompok yang belum pernah menggunakan layanan tersebut.

\section{METODOLOGI}

Melalui studi literatur yang telah dibahas di atas, model penelitian statistik deskriptif disusun dengan tujuan untuk mengembangkan studi empiris sebelumnya terhadap dua kelompok segmentasi Dewasa Muda yang diobservasi guna mengetahui lebih dalam perbedaan perilaku yang signifikan di antara dua kelompok tersebut dengan model statistik sederhana. Pertama, evaluasi umum terhadap empat persepsi 
kelompok yang diobservasi dilakukan berdasarkan pengembangan model Technology Acceptance Model (TAM) yang dilakukan oleh Malhotra dan Galletta (1999). Alat yang digunakan untuk mengukur evaluasi tersebut menggunakan skala tujuh poin peringkat bi-polar guna mengukur persepsi masing-masing kelompok terhadap penggunaan layanan daring perbankan; yaitu, apakah penggunaannya dipersepsikan sebagai konsep yang baik/tidak baik, bermanfaat/tidak bermanfaat, merupakan pilihan yang bijak/tidak bijak, dan apakah memberikan dampak yang positif/negatif.

Dengan mengetahui nilai mean (ratarata) pada setiap pengukuran, maka dapat diketahui secara umum mengenai perbedaaan kedua kelompok tersebut, terutama dalam hal bagaimana persepsi mereka secara umum terhadap layanan daring perbankan. Hipotesa yang dikembangkan dalam model penelitian ini adalah bahwa secara umum segmen Dewasa Muda "setuju” (min. skala 5) dengan layanan daring perbankan. Selanjutnya, dengan menggunakan metoda Differences Analysis, evaluasi lebih dalam dilakukan untuk mengetahui signifikansi kedua kelompok yang diobservasi. Hipotesa yang dikembangkan dalam metoda ini yaitu bahwa kelompok yang pernah menggunakan layanan daring perbankan sebelumnya mempersepsikan setidaknya dua dimensi, yaitu: manfaat dan dampak positif, sebagai dimensi yang secara signifikan berbeda dengan kelompok yang belum pernah menggunakan layanan daring perbankan.

Kedua, evaluasi dengan pengukuran manfaat dan risiko dikembangkan dengan menggunakan acuan empat pernyataan yang berkaitan dengan manfaat (perceived of usefulness) dikembangkan oleh Davis dan Veskantesh (1996), yaitu: sejauh mana penggunaan layanan daring perbankan dapat/mungkin dapat meningkatkan kinerja, menambah produktivitas, efektif, dan bermanfaat dalam menunjang obyek melakukan transaksi perbankan. Pengukuran dilakukan dengan skala Likert 1-7. Sama halnya seperti metoda yang dipaparkan sebelumnya, pengukuran dengan metoda Differences Analysis dilakukan untuk menguji hipotesa signfikansi perbedaan di antara kedua kelompok.

Ketiga, instrumen yang dilakukan untuk mengukur persepsi risiko dikembangkan dengan mengadopsi penelitian yang dilakukan oleh Jarvenpaa dan Todd (1996) dengan menggunakan deskripsi tiga macam pertanyaan yang seluruhnya menggambarkan risiko dalam melakukan belanja daring (online shopping) ditambah satu macam pertanyaan kombinasi yang menggambarkan pengaruh risiko-risiko secara keseluruhan berdasarkan alasanalasan lainnya. Ketiga dimensi risiko tersebut yaitu risiko yang dapat menyebabkan kerugian secara finansial, risiko sosial, karena lingkungan keluarga dan teman tidak menganjurkan penggunaan layanan daring perbankan, serta risiko karena alasan keamanan yang terkait dengan keamanan data pribadi. Seperti evaluasi yang pertama dan kedua, pengukuran ini juga dilanjutkan dengan Differences Analysis guna menguji hipotesa perbedaan dimensi persepsi yang signifikan di antara kedua kelompok.

Populasi dalam studi ini adalah kelompok Dewasa Muda yang berusia 16-29 tahun, yaitu mereka yang telah dewasa dan dalam kurun waktu enam bulan atau satu tahun ke depan layak mendaftarkan sebagai nasabah bank secara mandiri, baik yang sudah pernah melakukan layanan daring perbankan maupun yang belum pernah. Metoda sampling dalam studi ini menggunakan metoda purposive sampling dengan tambahan beberapa survei kecil untuk melengkapi keterwakilan responden 
yang tinggal/berasal dari seputar Jabodetabek dan di luar kota. Metoda purposive sampling dilakukan oleh petugas survei, yaitu mahasiswa S1 jurusan pemasaran, di mana mereka ditugaskan melakukan face-to-face administered questionnaire survey terhadap rekan-rekan mereka di kampus, staf universitas dan anggota keluarga mereka, baik di lingkungan kampus terdekat, maupun di universitas lainnya.

Dari pekerjaan pengumpulan data yang ditugaskan kepada petugas survei lapangan, sejumlah 88 responden terkumpul mengingat adanya batasan waktu dan dana dalam studi ini, dengan tetap memperhatikan keterwakilan sample serta realibilitas dan validitas data. Beberapa lembar kuesioner yang telah diisi tidak dapat dipergunakan karena kesalahan pengisian ataupun susunan halaman yang kurang tepat. Dari ke-88 responden yang telah diperoleh, sejumlah 53 responden berasal dari kelompok yang sudah berpengalaman menggunakan layanan daring perbankan, yaitu 27 responden pria dan 26 responden wanita. Sedangkan sisanya, 35 responden yang berasal dari kelompok yang belum berpengalaman melakukan layanan daring perbankan terdiri dari 11 responden pria dan 24 responden wanita.

\section{PEMBAHASAN DAN ANALISIS DATA}

Berdasarkan metoda penelitian dan hipotesa yang dibahas di bagian terdahulu, data primer yang diperoleh diolah dengan menggunakan bantuan piranti lunak IBM SPSS. Sebelum melakukan survei, uji kelayakan reliabilitas dan validitas dilakukan, dan hasil uji koefisien korelasi Pearson menunjukkan bahwa pengukuran terhadap dimensi kuesioner dengan skala interval memiliki respons yang identik dari sejumlah sample responden, terlihat dari hasil perhitungan Alpha Cronbach yang lebih besar dari 0.7. Dengan demikian instrumen dapat dilanjutkan untuk mendapatkan sample populasi. Dan setelah data primer diperoleh, maka analisa deskriptif dan diferensial layak diolah guna menguji hipotesa terhadap persepsi secara umum, persepsi terhadap manfaat, serta persepsi terhadap risiko penggunaan layanan daring perbankan dari dua kelompok yang berbeda.

\subsection{Persepsi Umum}

Dengan menggunakan uji statistik One-Sample T, studi ini akan menguji hipotesa bahwa secara umum segmen Dewasa Muda menerima atau "setuju" dengan layanan daring perbankan sebagaimana terlihat di Tabel 1. dan Tabel 2.

Tabel 1.

Hasil Uji Persepsi Umum dengan One-Sample T Terhadap Kelompok yang Berpengalaman

\begin{tabular}{|l||c||c||c||c||}
\hline \multicolumn{1}{|c||}{ Dimensi } & $\mathbf{N}$ & Mean & Std. Deviation & Std. Error Mean \\
\hline \hline Konsep yg baik & 53 & 5.83 & 1.205 & 0.165 \\
\hline \hline Bermanfaat & 53 & 6.11 & 0.934 & 0.128 \\
\hline \hline Pilihan yg bijak & 53 & 5.58 & 1.184 & 0.163 \\
\hline \hline Berdampak positf & 53 & 5.77 & 1.086 & 0.149 \\
\hline
\end{tabular}

Hasil yang diperoleh dari uji $\mathrm{T}$ menunjukkan bahwa kedua kelompok memiliki kemiripan nilai mean dengan interval berjarak 5.03 - 6.1. Karena semua nilainya lebih besar dari pada lima (5), maka secara umum hipotesa terhadap kedua 
kelompok dapat diterima atau dengan kata lain, kedua kelompok "setuju" dengan adanya layanan daring perbankan. Dengan studi statistik lebih mendalam melalui metoda uji Independent-Samples sebagaimana terlihat di Tabel 3. ditemukan bahwa kedua kelompok secara signifikan berbeda.

Tabel 2.

Hasil Uji Perspesi Umum dengan One-Sample T Terhadap Kelompok yang Belum Berpengalaman

\begin{tabular}{|l||c||c||c||c||}
\hline \multicolumn{1}{|c||}{ Dimensi } & $\mathbf{N}$ & Mean & Std. Deviation & Std. Error Mean \\
\hline \hline Konsep yg baik & 35 & 5.54 & 1.067 & 0.180 \\
\hline Bermanfaat & 35 & 5.46 & 1.172 & 0.198 \\
\hline \hline Pilihan yg bijak & 35 & 5.03 & 1.071 & 0.181 \\
\hline \hline Berdampak positf & 35 & 5.14 & 1.375 & 0.232 \\
\hline
\end{tabular}

Perbedaan terlihat pada nilai Sig. 2tailed dalam Tabel 3., yaitu berturut-turut sebesar 0.255, 0.007, 0.025, and 0.019, dimana dilaporkan bahwa dari keempat nilai tersebut hanya satu variabel yang memiliki kesamaan, yaitu bahwa layanan daring perbankan merupakan konsep yang baik dengan nilai Sig. 2-tailed 0.255 (perbedaan tidak signifikan). Dengan demikian hipotesa diterima, bahwa setidaknya dari dua kelompok tersebut ada dua variabel yang memiliki perbedaan yang signifikan, yaitu manfaat dan dampak positif dengan nilai Sig. 2-tailed masing-masing 0.007 dan 0.019 . Disamping itu ada temuan lainnya, bahwa dari dua kelompok tersebut persepsi pilihan yang bijak terhadap layanan daring perbankan secara signifikan berbeda, dengan nilai Sig. 2-tailed 0.025 .

Tabel 3.

Hasil Uji Persepsi Umum dengan Independent-Samples T Terhadap Dua Kelompok

\begin{tabular}{|c|c|c|c|c|}
\hline \multirow[t]{2}{*}{ Koefisien } & \multicolumn{4}{|c|}{ Nilai } \\
\hline & Konsep yg baik & Bermanfaat & Pilihan Bijak & Dampak Positif \\
\hline $\begin{array}{l}\text { Levene's Test for } \\
\text { Equality of Variance }\end{array}$ & & & & \\
\hline Equal variances assumed & & & & \\
\hline F-test value & 0.196 & 4.718 & 4.013 & 0.530 \\
\hline Sig. value & 0.659 & 0.033 & 0.048 & 0.469 \\
\hline $\begin{array}{l}\text { T-test for Equality of } \\
\text { Means }\end{array}$ & & & & \\
\hline Significance (Sig.) 2-tailed & & & & \\
\hline Equal variances assumed & 0.255 & 0.005 & 0.028 & 0.019 \\
\hline $\begin{array}{l}\text { Equal variances not } \\
\text { assumed }\end{array}$ & 0.287 & 0.007 & 0.025 & 0.026 \\
\hline Means Difference & 0.287 & 0.656 & 0.556 & 0.631 \\
\hline
\end{tabular}

\subsection{Manfaat}

Tabel 4. dan Tabel 5. melaporkan hasil pengolahan data antara dua kelompok responden yang sudah dan belum pernah menggunakan layanan daring perbankan dengan uji One-Sample T. Secara deskriptif dapat digambarkan bahwa nilai rata-rata atau mean kelompok responden yang 
berpengalaman lebih besar daripada kelompok responden yang belum berpengalaman.

Lebih lanjut dengan melakukan analisis diferensial, hasil uji signifikansi Independent-Samples $\mathrm{T}$ terhadap keempat dimensi manfaat yang dilaporkan dalam Tabel 6. menunjukkan bahwa kelompok pertama (berpengalaman) berbeda secara signifikan terhadap kelompok kedua (belum berpengalaman). Perbedaaan kedua kelompok ini sangat signifikan secara berturut-turut, dapat dilihat dari nilai uji Sig. 2-tailed di setiap dimensi pengukuran, yaitu $0.003,0.000,0.000$, dan 0.000 , dan dengan demikian hipotesa dapat diterima.

Dengan kata lain, bahwa kelompok yang sudah berpengalaman menggunakan layanan daring perbankan lebih merasakan manfaat yang nyata dibandingkan persepsi manfaat kelompok yang belum pernah melakukan layanan daring perbankan.

Tabel 4.

Hasil Uji Manfaat dengan One-Sample Terhadap Kelompok yang Berpengalaman

\begin{tabular}{|l||r||r||r||r||}
\hline \multicolumn{1}{|c|}{ Dimensi } & N & \multicolumn{1}{c||}{ Mean } & Std. Deviation & Std. Error Mean \\
\hline \hline $\begin{array}{l}\text { Meningkatkan kemampuan dalam melakukan } \\
\text { transaksi perbankan }\end{array}$ & 53 & 5.57 & 1.029 & 0.141 \\
\hline $\begin{array}{l}\text { Menambah produktivitas dalam melakukan } \\
\text { transaksi perbankan }\end{array}$ & 53 & 5.55 & 1.280 & 0.176 \\
\hline \hline Transaksi perbankan menjadi lebih efektif & 53 & 5.85 & 1.099 & 0.151 \\
\hline $\begin{array}{l}\text { Bermanfaat dalam menunjang transaksi } \\
\text { perbankan }\end{array}$ & 53 & 5.85 & 0.988 & 0.136 \\
\hline
\end{tabular}

Tabel 5.

Hasil Uji Manfaat dengan One-Sample Terhadap Kelompok yang Belum Berpengalaman

\begin{tabular}{|l||r|r||r||r||}
\hline \multicolumn{1}{|c|}{ Dimensi } & \multicolumn{1}{|c|}{ N } & \multicolumn{1}{|c|}{ Mean } & \multicolumn{1}{|c|}{ Std. Deviation } & Std. Error Mean \\
\hline \hline $\begin{array}{l}\text { Meningkatkan kemampuan dalam melakukan } \\
\text { transaksi perbankan }\end{array}$ & 35 & 5.00 & 0.686 & 0.116 \\
\hline $\begin{array}{l}\text { Menambah produktivitas dalam melakukan } \\
\text { transaksi perbankan }\end{array}$ & 35 & 4.66 & 0.968 & 0.164 \\
\hline \hline Transaksi perbankan menjadi lebih efektif & 35 & 4.94 & 0.802 & 0.136 \\
\hline $\begin{array}{l}\text { Bermanfaat dalam menunjang transaksi } \\
\text { perbankan }\end{array}$ & 35 & 5.03 & 0.785 & 0.133 \\
\hline
\end{tabular}

Tabel 6.

Hasil Uji Manfaat dengan Independent-Samples T Terhadap Dua Kelompok

\begin{tabular}{|l|r||r|r||r||}
\hline \multicolumn{1}{|c|}{ Koefisien } & \multicolumn{1}{c||}{ Manfaat-3 } & Manfaat-4 \\
\cline { 2 - 5 } & \multicolumn{1}{|c|}{ Manfaat-1 } & Manfaat-2 & \multicolumn{1}{c||}{} \\
\hline \hline $\begin{array}{l}\text { Levene's for } \\
\text { Equality of Variance }\end{array}$ & & & & \\
\hline \hline Equal variances assumed & & & & \\
\hline \hline F-test value & 24.372 & 6.477 & $\mathbf{0 . 0 0 0}$ & $\mathbf{0 . 0 0 1}$ \\
\hline \hline Sig. value & $\mathbf{0 . 0 0 0}$ & $\mathbf{0 . 0 1 3}$ & & \\
\hline
\end{tabular}




\begin{tabular}{|l|r||r||r|r||}
\hline $\begin{array}{l}\text { T-test for Equality of } \\
\text { Means }\end{array}$ & & & \\
\hline \hline Significance (Sig.) 2-tailed & & & & \\
\hline \hline Equal variances assumed & 0.005 & 0.001 & 0.000 & 0.000 \\
\hline $\begin{array}{l}\text { Equal variances not } \\
\text { assumed }\end{array}$ & $\mathbf{0 . 0 0 3}$ & $\mathbf{0 . 0 0 0}$ & $\mathbf{0 . 0 0 0}$ & $\mathbf{0 . 0 0 0}$ \\
\hline Means Difference & 0.566 & 0.890 & 0.906 & 0.820 \\
\hline \hline
\end{tabular}

\subsection{Risiko}

Hasil pengolahan data persepsi risiko dengan One-Sample $\mathrm{T}$ dapat dilihat pada Tabel 7. guna melihat persepsi kelompok yang sudah berpengalaman menggunakan layanan daring perbankan. Hasil nilai mean yang dilaporkan dalam Tabel 7. ternyata cukup bervariatif. Walaupun semuanya di bawah nilai lima (5), yang artinya "kemungkinan berisiko", dapat dilihat sejauh mana tingkat risiko tiap-tiap dimensi. Dilaporkan berturut-turut mulai dari yang bernilai terbesar sampai dengan yang terkecil adalah: pertama, karena faktor keamaanan data pribadi, di mana nilai meannya adalah 4.00, artinya bahwa layanan perbankan "bisa ya atau tidak" berisiko. Yang kedua, faktor risiko kerugian finansial, dengan nilai mean 3.72. Dan yang ketiga, karena faktor sosial, yaitu keluarga dan teman tidak menganjurkan penggunaan layanan daring perbankan, dengan nilai mean 2.96, yang mendekati 3.00 , yang artinya bahwa kemungkinan layanan daring perbankan tidak berisiko. Namun demikian secara keseluruhan, kelompok ini memiliki nilai mean 3.87 untuk pertimbangan faktor risiko-risiko lainnya.

Sebagaimana dilaporkan dalam uji One-Sample T pada Tabel 8., kelompok yang belum berpengalaman menggunakan layanan daring perbankan memiliki kemiripan peringkat persepsi risiko sebagaimana kelompok yang pertama. Secara berturutturut faktor yang berperan adalah pertama, karena alasan keamanan data pribadi dengan nilai mean 4.26. Yang kedua, dapat menyebabkan kerugian finansial dengan nilai mean 4.14. Dan yang ketiga adalah karena keluarga dan teman tidak menganjurkannya dengan nilai mean 3.51. Secara keseluruhan berdasarkan alasan risiko-risiko lainnya, kelompok ini memiliki nilai mean yang lebih tinggi daripada kelompok yang sebelumnya, yaitu sebesar 4.26.

Studi yang lebih mendalam dilakukan untuk menguji hipotesa perbedaan signifikan di antara kedua kelompok terhadap persepsi risiko penggunaan layanan daring perbankan, sebagaimana lebih lanjut dilaporkan pada Tabel 9. dengan uji Independent-Samples $\mathrm{T}$.

Tabel 7.

Hasil Uji Risiko dengan One-Sample T terhadap Kelompok yang Berpengalaman

\begin{tabular}{|l||c|r||r||r||}
\hline \multicolumn{1}{|c|}{ Dimensi } & N & Mean & Std. Deviation & Std. Error Mean \\
\hline \hline Dapat menyebabkan kerugian finansial & 53 & 3.72 & 1.419 & 0.195 \\
\hline $\begin{array}{l}\text { Keluarga dan teman tidak menganjurkan } \\
\text { penggunaan }\end{array}$ & 53 & 2.96 & 1.400 & 0.192 \\
\hline Data pribadi tidak aman & 53 & 4.00 & 1.441 & 0.198 \\
\hline \hline Risiko-risiko lainnya secara keseluruhan & 53 & 3.87 & 1.373 & 0.189 \\
\hline
\end{tabular}


Tabel 8.

Hasil Uji Risiko dengan One-Sample T terhadap Kelompok yang Belum Berpengalaman

\begin{tabular}{|l||r||r||r|r||}
\hline \multicolumn{1}{|c|}{ Dimensi } & N & \multicolumn{1}{|c|}{ Mean } & Std. Deviation & Std. Error Mean \\
\hline \hline Dapat menyebabkan kerugian finansial & 35 & 4.14 & 1.004 & 0.170 \\
\hline \hline $\begin{array}{l}\text { Keluarga dan teman tidak menganjurkan } \\
\text { penggunaan }\end{array}$ & 35 & 3.51 & 1.269 & 0.214 \\
\hline Data pribadi tidak aman & 35 & 4.26 & 1.379 & 0.233 \\
\hline \hline Risiko-risiko lainnya secara keseluruhan & 35 & 4.26 & 1.172 & 0.198 \\
\hline
\end{tabular}

Tabel 9.

Hasil Uji Risiko dengan Independent-Samples T Terhadap Dua Kelompok

\begin{tabular}{|c|c|c|c|c|}
\hline \multirow{2}{*}{ Koefisien } & \multicolumn{4}{|c|}{ Nilai } \\
\hline & Risiko-1 & Risiko-2 & Risiko-3 & Risiko-4 \\
\hline $\begin{array}{l}\text { Levene's Test for } \\
\text { Equality of Variance }\end{array}$ & & & & \\
\hline Equal variances assumed & & & & \\
\hline F-test value & 7.112 & 1.751 & 0.130 & 1.517 \\
\hline Sig. value & 0.009 & 0.189 & 0.719 & 0.222 \\
\hline $\begin{array}{l}\text { T-test for Equality of } \\
\text { Means }\end{array}$ & & & & \\
\hline Significance (Sig.) 2-tailed & & & & \\
\hline Equal variances assumed & 0.128 & 0.064 & 0.407 & 0.172 \\
\hline $\begin{array}{l}\text { Equal variances not } \\
\text { assumed }\end{array}$ & 0.103 & 0.059 & 0.403 & 0.159 \\
\hline Means Difference & -0.426 & -0.552 & -0.257 & -0.389 \\
\hline
\end{tabular}

Dengan melihat hasil pengukuran di atas, maka dapat dianalisis bahwa kelompok yang sudah berpengalaman dan kelompok yang belum berpengalaman, tidak memiliki perbedaaan yang signifikan dalam hal persepsi terhadap risiko layanan daring perbankan. Hasil uji memperlihatkan secara berturut-turut nilai Sig. 2-tailed setiap dimensi adalah 0.103, 0.064, 0.407, dan 0.172 , yang semuanya lebih besar dari 0.05 (tidak signifikan), sehingga dengan demikian hipotesa ditolak. Atau dengan lain, kelompok yang pertama memiliki persepsi yang tidak jauh berbeda dengan kelompok yang kedua dalam hal mempersepsikan faktor risiko dalam penggunaan layanan daring perbankan.

\section{PENUTUP}

Studi ini dilakukan dengan tujuan menggali perbedaan persepsi kelompok Dewasa Muda terhadap penggunaan layanan daring perbankan, baik kelompok yang sudah pernah melakukan layanan daring perbankan, maupun yang belum pernah. Pertama, hasil studi menggambarkan bahwa kelompok pertama memiliki kesamaan dengan kelompok yang kedua dalam hal mempersepsikan penggunaan layanan daring perbankan secara umum, karena keduanya terbukti menerima konsep layanan ini dengan baik. Ketika diuji dengan lebih mendalam, kedua kelompok ini setidaknya memiliki dua macam perbedaan yang signifikan dalam merasakan manfaat dan dampak positif yang diberikan oleh layanan 
daring perbankan. Artinya, kelompok pertama, karena sudah berpengalaman (experience) melakukan layanan, akan merasakan manfaat nyata dan dampak positif yang diterimanya, dibandingkan dengan mereka yang belum pernah melakukannya. Faktor pengalaman pengguna (user experience) diteliti lebih lanjut oleh penulis secara terpisah dalam sebuah studi interaksi manusia dan teknologi informasi terkait dengan pemanfaatan layanan daring perbankan dengan memanfaatkan data dari studi yang sama. Hasil temuan dalam studi ini diharapkan dapat membantu para perancang situs (website designers) ataupun para manajer produk/manajer pemasaran perbankan guna mempertimbangkan faktor "user experience" dalam strategi mempromosikan produk-produknya, terutama terkait dengan produk-produk electronic banking.

Dalam hal persepsi "pilihan yang bijak” yang dilaporkan memiliki perbedaan secara signifikan di antara kedua kelompok, hipotesa yang pertama diperkuat. Artinya, kelompok kedua walaupun sama-sama "setuju” dengan kelompok pertama dalam menggunakan layanan ini sebagai konsep yang baik, namun masih melihat bahwa layanan ini relatif belum menjadi opsi yang utama, bila dibandingkan dengan kelompok yang pertama. Penelitian lebih lanjut mengenai persepsi opsi dan kualitas layanan daring perbankan (misalnya dibandingkan dengan kualitas layanan tradisional perbankan), mungkin dapat mengungkap lebih lanjut perilaku konsumen dan kebutuhan nasabah bank dengan lebih konkrit. Selain itu penelitian ini juga dapat menjadi salah satu acuan dalam mengukur tingkat loyalitas konsumen dalam menggunakan beragam opsi layanan perbankan.

Yang kedua, dalam hal mempersepsikan manfaat, hasil studi ini secara konsisten melaporkan bahwa kedua kelompok memiliki perbedaan yang signifikan. Walaupun berbeda, keduanya dilaporkan memiliki kesamaan prioritas pada peringkat "setuju" (nilai mean $\geq 5$ ), yaitu bahwa layanan daring perbankan bermanfaat dalam menunjang transaksi perbankan. Atau dengan kata lain, kedua kelompok segmen Dewasa Muda, baik yang sudah pernah menggunakan layanan daring atau belum, merasa bahwa layanan daring sudah menjadi kebutuhan (needs) bagi para nasabah perbankan. Sebagai implikasinya, para manajer pemasaran bank dapat melihat hal ini sebagai kesempatan untuk menciptakan nilai tambah layanan perbankannya, terutama bagi segmen Dewasa Muda yang belum berkesempatan menikmati layanan daring perbankan. Penelitian lebih lanjut mungkin dapat mengungkap apakah kelompok yang belum berpengalaman setelah beralih menjadi nasabah daring perbankan mampu menjadi nasabah yang lebih loyal dibandingkan sebelumnya. Selain itu, dapat juga diteliti sejauh mana peran kedua kelompok dalam merekomendasikan manfaat layanan daring perbankan kepada keluarga dan teman-teman mereka sehingga dapat menjadi masukan berharga bagi manajer pemasaran bank dalam memperluas jaringan nasabahnya.

Yang ketiga, dengan melalui pengujian analisis diferensial, hasil studi ini melaporkan bahwa kedua kelompok segmen Dewasa Muda tidak memiliki perbedaan yang signifikan dalam melihat risiko layanan daring perbankan. Kedua kelompok secara konsisten memperlihatkan bahwa di antara keempat dimensi risiko, faktor keamanan data pribadi merupakan hal yang penting dalam layanan daring perbankan. Temuan ini dapat menjadi bahan masukan bagi para manajer keamanan informasi bank untuk secara terus menerus dapat memberikan layanan yang lebih terpercaya dalam 
menjaga kerahasiaan dan keamanan informasi data pribadi para nasabahnya. Penelitian lebih lanjut mengenai topik ini dapat diperluas dengan mengetahui sejauhmana loyalitas nasabah dipengaruhi oleh faktor keamanan dalam layanan daring perbankan. Mengingat obyek yang diteliti adalah segmen Dewasa Muda, maka penelitan dapat dikembangkan lebih lanjut guna mengetahui seberapa kuat faktor keamanan data pribadi berpengaruh pada perilaku bertansaksi melalui Internet dan memiliki hubungan dengan pola atau perilaku mereka terhadap kegiatan bisnis daring (e-commerce) di masa yang akan datang.

Mengingat bahwa studi ini menggunakan metoda penelitian statistik deskriptif dan inferensial sederhana dengan mengungkapkan signifikansi kedua kelompok segmen Dewasa Muda, maka penelitian dengan metodologi yang lebih kompleks diperlukan agar dapat mengungkap temuan-temuan baru. Disamping itu karena penelitian ini bersifat cross sectional maka penelitian dapat dikembangkan lebih lanjut dengan dengan pengambilan sample yang lebih luas guna mengurangi eror dan meningkatkan akurasi hasil penelitian. Dan akhirnya penulis berharap agar studi kecil ini dapat bermanfaat bagi para pelaku bisnis khususnya dunia perbankan yang sedang membenahi diri dari waktu ke waktu sehingga dapat memberikan layanan jasa keuangan yang lebih efisien kepada masyarakat. 


\section{DAFTAR PUSTAKA}

Ajzen I, 1991, “The theory of planned behavior.”, Organizational Behavior and Human Decision Processes Journal, Vol. 50(2), pp:121-79.

Chau, V.S, dan Ngai, L.W.L.C. 2010, "The youth market for internet banking services: perceptions, attitude and behaviour.”, Journal of Services Marketing, Vol. 24/1, pp: 42-60.

Davis, F.D., 1989, "Perceived usefulness perceived ease of use and user acceptance of information technology.”, Management Information System Quarterly, Vol. 13(3), pp:318-40.

Davis, F.D. dan Venkatesh, V. 1996, "A critical assessment of potential measurement biases in the technology acceptance model: three experiments”, International Journal of Human-Computer Studies, Vol. 45 No. 1, pp. 19-45.

“E-banking”, retrieved from Wikipedia http://id.wikipedia.org/wiki/E-banking tanggal 4-May-2014

Jarvennpaa, S.L. and Todd, P.A. 1996, "Consumer reactions to electronic shopping on the world wide web", International Journal of Electronic Commerce, Vol. 1 No. 2, pp. 59-88.

Kuisma T., Laukkanen T., dan Hiltunen M. , 2007, "Mapping the reasons for resistance to internet banking: a means-end approach.”, International Journal of Information Management,Vol.27(2), pp:75-85.

Laudon, K.C dan Traver, C.G. 2012. "E-Commerce 2012: Business. Technology. Society, Eigth Ed.”, Prentice Hall, pp: 752-763.

Lee, Ming-Chi. 2009. "Factors Influencing the Adoption of Internet Banking: An Integration of TAM and TPB with Perceived Risk and Perceived Benefit.” Journal of Electronic Commerce Research and Applications , Vol. 8, pp: 130-141.

Littler, D., Melanthiou D. 2006, "Consumer perceptions of risk and uncertainty and the implications for behaviour towards innovative retail services: the case of internet banking.", Journal of Retailing and Consumer Services, Vol. 13(6):431-43.

Malhotra, Y. and Galletta, D.F. 1999, "Extending the technology acceptance model to account for social influence: theoretical bases and empirical validation”, Proceedings of 32nd Hawaii International Conference on System Sciences.

“Millennials Invest More Time in Digital Banking: Online and mobile banking make millennials' lives easier", retrieved from http://www.emarketer.com/Article/Millennials-Invest-More-Time-DigitalBanking/1010704 tanggal 7-Juni-2014.

Sejarah Internet Indonesia/e-banking, retrived from Wikibook http://id.wikibooks.org/wiki/Sejarah_Internet_Indonesia/e-banking tanggal 4-May-2014.

Turban, E., King, D., Lee, J., Liang, T.P., dan Turban, D., (2012). Electronic Commerce 2012: A Managerial and Social Networks Perspective, Global Edition, Prentice Hall, pp: 158-162.

Winarko, B. dan Mahadewi, L. (2013). "Tinjauan Beberapa Model Teori Dasar Adopsi Teknologi Baru”, Jurnal Media Bisnis, Trisakti School of Management, Vol. 5 No. 1, March 2013. 